\section{ANALIZA STAVOVA KORISNIKA O NAPLATI PUTARINE NA AUTOPUTEVIMA REPUBLIKE SRBIJE}

Marina Milenković, mast. inž. saobr.

Saobraćajni fakultet, Univerzitet u Beogradu, marina.milenkovic@sf.bg.ac.rs

dr Draženko Glavić, dip. inž. saobr.

Saobraćajni fakultet, Univerzitet u Beogradu, drazen@sf.bg.ac.rs

Marina Lukić, mast. inž. saobr.

marina.lukic93@gmail.com

Stručni rad

Rezime: Naplata putarine na autoputevima predstavlja mehanizam za finansiranje izgradnje putne infrastrukture, njenu eksploataciju $i$ održavanje. Cilj ovog rada je da se izvrši analiza stavova korisnika o naplati putarine na autoputevima Srbije. U tu svrhu je definisana anketa koja je sadržala kako pitanja o socio-ekonomskim karakteristikama korisnika, tako i pitanja o naplati putarine. Anketa je sprovedena elektronskim putem i uzorak je činilo 680 ispitanika. Za obradu podataka korišćene su metode deskriptivne statistike. Dobijeni rezultati će pomoći donosiocima odluka prilikom definisanja strategije naplate putarine, koja bi trebala da doprinese unapređenju postojećeg sistema naplate putarine u Srbiji.

Ključne reči: sistemi za naplatu putarine, strategija naplate putarine, anketa

\section{ANALYSIS OF USERS' ATTITUDES TOWARDS TOLLING ON THE REPUBLIC OF SERBIA MOTORWAYS}

Marina Milenković, M.Sc. T.E.

Faculty of Transport and Traffic Engineering, University of Belgrade, marina.milenkovic@sf.bg.ac.rs

Draženko Glavić, PhD. T.E.

Faculty of Transport and Traffic Engineering, University of Belgrade, drazen@sf.bg.ac.rs

Marina Lukić, M.Sc. T.E.

marina.lukic93@gmail.com

Proffessional paper

Abstract: Toll collection goal on motorways refers to the mechanism for financing the construction of road infrastructure, its operation and maintenance. The aim of this paper is to analyze the users' attitudes towards toll charging on the motorway network of the Republic of Serbia. For that purpose, a survey was defined containing both questions about the users' socio-economic characteristics, as well as the questions of toll collection. The survey was conducted electronically and the sample consists of 680 respondents. For data processing, some of the descriptive statistics methods were used. The obtained results will help the decision makers in defining the toll collection strategy that would contribute to the improvement of the existing toll collection system in Serbia.

Keywords: toll collection systems, toll charging strategy, survey

\section{UVOD}

Naplata putarine na autoputevima predstavlja direktnu naknadu za korišćenje autoputa kao putne infrastrukture. Cilj ove naknade je da se obezbede sredstva za finansiranje izgradnje putne infrastrukture, njenu eksploataciju i održavanje. Naplata putarine može biti zasnovana na vremenskoj naknadi ili na naknadi zasnovanoj na pređenim kilometrima. Takođe, danas se u svetu koristi veliki broj tehnologija i sistema za naplatu putarine. Sistemi naplate koji se danas koriste $u$ svetu se mogu podeliti $u$ tri osnove grupe: sistemi koji zahtevaju zaustavljanje, sistemi koji zahtevaju smanjenje brzine $\mathrm{i}$ oni koji ne zahtevaju nikakvu promenu brzine.

U Srbiji, naplata putarine se obavlja na mreži autoputeva, ukupne dužine oko $645 \mathrm{~km}$. Prema podacima iz 2017. god. sistem putarine se sastoji od 47 naplatnih stanica i naplata putarine se sprovodi na sledećim putnim pravcima:

- Beograd-Niš;

- Beograd-Šid;

- Niš-Leskovac-Preševo;

- Niš-Dimitrovgrad;

- Beograd-Subotica; i

- Beograd-Požega.

Naplata putarine je zasnovana na pređenim kilometrima i visina naknade zavisi od naplatne kategorije vozila. Naplata se odvija u uslovima zatvorenog sistema, osim kod putnih pravaca kod kojih nije izvršena izgradnja pojedinih deonica. Nakon kompletne izgradnje određenih putnih pravaca, zatvoren sistem za naplatu putarine će na celokupnoj mreži autoputeva Srbije zameniti otvoreni sistem za naplatu putarine.

Od sistema za naplatu putarine u Srbiji su zastupljeni manuelni sistem, koji zahteva zaustavljanje vozila, i tzv. elektronski sistem sa barijerama (DSRC with barriers) koji zahteva promenu brzine vozila prilikom prolaska vozila kroz naplatnu stanicu.

Cilj rada je da se izvrši analiza stavova korisnika o postojećem stanju sistema za naplatu putarine $u$ Srbiji. Poseban akcenat biće stavljen na informisanost korisnika autoputeva i njihove stavove o trenutnom nivou usluge koji im je obezbeđen na mreži autoputeva Srbije.

Dobijeni rezultati će pružiti detaljan uvid u postojeće stanje, uzročnike mogućih problema i na određen način predstavljaće smernice koje bi eksperti trebalo uzeti u obzir prilikom unapređenja sistema za naplatu putarine u Srbiji. 


\section{PREGLED LITERATURE}

Pregledom inostrane literature utvrđeno je da je prihvatljivost naplate putarine veća u sledećim slučajevima: (1) kada su svrha i korist primene sistema naplate jasno definisani i razumljivi korisnicima; (2) kada su ciljevi implementacije naplate u skladu sa postojećim problemima i (3) ako su prihodi od naknade iskorišćeni u transportnom sektoru (Odeck \& Bråthen 2002; Gaunt et al. 2007). Kada je reč o spremnosti korisnika da plate za korišćenje autoputa ili odustanu od putovanja autoputem, kao ključni faktori koji utiču na stavove korisnika u literaturi se navode: tip puta, svrha putovanja, ukupno vreme putovanja, učestalost korišćenja autoputa, procenjen rizik od saobraćajnih nezgoda, itd.

Gomez et al. (2016) su u Španiji sproveli istraživanje stavova korisnika prema naplati putarine, sa ciljem da utvrde da li razlike u regionima utiču na stavove korisnika. Tom prilikom su prikupili podatke za 2.769 korisnika i na osnovu dobijenih rezultata došli do zaključka da se percepcija korisnika prema naplat putarine može u velikoj meri razlikovati od regiona do regiona unutar iste države. Drugim rečima stavovi korisnika prema putnim troškovima u velikoj meri zavise od samog geografskog položaja, odnosno regiona gde se planira uvođenje naplate putarine.

Glavić et al. (2017) sproveli su istraživanje koje je imalo za cilj da ispita stavove korisnika po pitanju voljnosti da plate korišćenje autoputa i spremnosti da odustanu od putovanja. Istraživanje je sprovedeno na teritoriji Bosne i Hercegovine, a tom prilikom je anketirano 15.321 korisnika. Rezultati do kojih su došli ukazuju na nekoliko važnih zaključaka. Pre svega, pokazuju da većina ispitanika prihvata cenu putarine do $5 €$, a da je manje od $4 \%$ onih koji su spremni da plate više od navedene vrednosti. Procenjena prosečna vrednost putarine iznosi oko 2 $€$.

Zmud \& Arce (2008) sproveli su analizu percepcije korisnika sa aspekta prihvatljivosti naplate putarine. Analiza je zasnovana na kompilaciji 110 anketa $i$ dubinskih analiza o naplati putarine. Rezultati ove kvantitativne analize ukazuju da u ukupnom broju ispitanika postoji većinska podrška za naplatu putarine. Drugim rečima, na osnovu svih analiza i rezultata pojedinačnih anketa, $56 \%$ ispitanika podržava koncept naplate za korišćenje putne mreže. $31 \%$ ispitanika ima suprotne stavove, dok $13 \%$ njih nema jasno definisane stavove po tom pitanju.

Ciommo et al. (2013) navode da se politika određivanja cene putarine za mrežu evropskih puteva suočava sa značajnim problemima u pogledu prihvatljivosti od strane korisnika.
Rezultati njihove studije ukazuju da se prihvatljivost povećava kada je uspostavljena fer naplata. Iz tog razloga upravljači puta, odnosno donosioci odluka treba da teže promovisanju ovakvih sistema sa ciljem povećanja prihvatljivosti od strane korisnika u pogledu naplate putarine.

\section{METODOLOGIJA}

Za prikupljanje podataka korišćen je metod ankete. Anketa je sadržala opšta pitanja o socioekonomskim karakteristikama ispitanika i pitanja o stavovima korisnika o postojećem stanju sistema za naplatu putarine i nivou usluge koja im je pružena na mreži sa naplatom - autoputevima. Za ocenu stavova korisnika korišćena je petostepena Likertova skala.

Anketa je sprovedena elektronskim putem i uzorak je činilo 680 ispitanika. Akcenat je na ciljnoj grupi korisnika puteva, od vozača privatnih automobila do vozača u špediterskim firmama. Istraživanjem su obuhvaćeni korisnici na celokupnoj mreži autoputeva u Srbiji. Anketiranje je sprovedeno u periodu od 10 dana, od 10. do 20. oktobra 2017. godine.

$\mathrm{Za}$ analizu podataka korišćene su standardne metode deskriptivne statistike.

\section{REZULTATI}

$U$ istraživanju je učestvovalo $62 \%$ ispitanika muškog pola i $38 \%$ ispitanika ženskog pola. Među anketiranim korisnicima najviše je onih uzrasta od 18-25 godina (36\%), zatim slede korisnici starosne dobi od 35 do 44 godina (23\%), korisnici starosne dobi od 26-34 godina (19\%), korisnici starosne dobi 45-54 godina (11\%), korisnici od 55 do 65 godina $(9 \%)$ i korisnici starosne dobi $+65(2 \%)$.

Među anketiranim korisnicima najviše je onih koji koriste autoput 1-3 puta mesečno (34\%). 20\% ispitanika je izjavilo da svakodnevno koristi autoput, dok $23 \%$ ispitanika koristi autoput 1-3 puta sedmično. Procenat onih koji autoput koriste retko (1-3 puta godišnje) takođe iznosi $23 \%$.

Najveći broj ispitanika koristi putnički automobil (91\%). Teretno vozilo koristi $6 \%$ ispitanika, autobus $2 \%$ ispitanika i kombi vozilo svega $1 \%$ ispitanika.

Polovina ispitanika koristi autoput za putovanja preko $90 \mathrm{~km}$. 33\% ispitanika koristi autoput za udaljenosti do $60 \mathrm{~km}$, dok $17 \%$ ispitanika koristi autoput za udaljenosti od $60 \mathrm{~km}$ do $90 \mathrm{~km}$.

Rezultati istraživanju su pokazali da čak $28 \%$ ispitanika izbegava korišćenje autoputa i koristi alternativni put, dok $72 \%$ anketiranih ne izbegava korišćenje autoputa i plaćanje putarine. 
$\mathrm{Na}$ Grafikonu 1 prikazani su glavni razlozi izbegavanja korišćenja autoputa. Sa Grafikona 1 može se videti da je glavni razlog izbegavanja korišćenja autoputa cena putarine (čak $76 \%$ ). 18\% ispitanika je kao glavni razlog izbegavanja autoputa navelo velike vremenske gubitke na naplatnim stanica, a $6 \%$ ispitanika izbegava korišćenje autoputa zbog velikih brzina vozila koja se kreću ovom kategorijom puta.

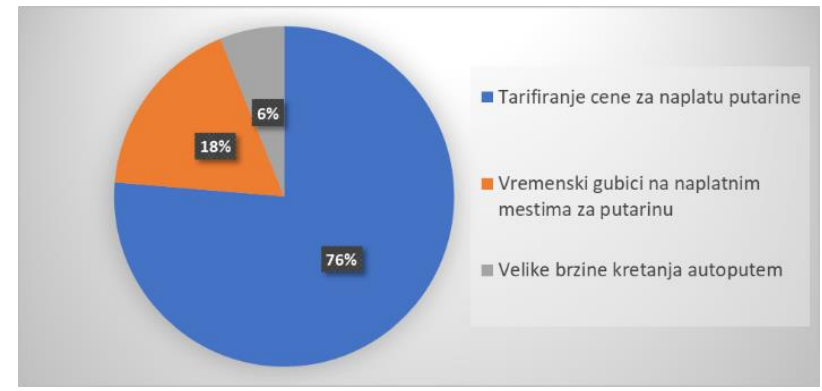

Grafikon 1. Razlozi izbegavanja korišćenja autoputa

Među anketiranim korisnicima $88 \%$ je izjavilo da bi se kretalo češće autoputem ako bi tarifiranje putarine bilo povoljnije. Najveći procenat ispitanika (75\%) smatra da je za svakodnevne korisnike godišnja preplata putarine povoljnija u odnosu na putarinu u skladu sa pređenim kilometrima, dok $25 \%$ korisnika smatra suprotno, odnosno da je povoljnije plaćanje po pređenom kilometru. Na pitanje koji sistem naplate je povoljniji za one koji koriste autoput 1-3 puta godišnje, $83 \%$ ispitanika je odgovorilo da je najpovoljniji način plaćanja po pređenom kilometru, dok $17 \%$ smatra da je pogodno platiti korišćenje autoputa na sedmičnom nivou.

Pojedina pitanja ankete odnosila su se na informisanost korisnika o postojećim sistemima za naplatu putarine. Rezultati ove analize su pokazali da je čak $81 \%$ anketiranih korisnika izjavilo da poseduje znanje o tipovima sistema za naplatu putarine, dok $19 \%$ anketiranih nije upoznato sa tipovima sistema za naplatu putarine. $\mathrm{Na}$ pitanje koji sistem naplate putarine koristi TAG uređaj, 95\% ispitanika je dalo tačan odgovor. Mogućnost plaćanja putarine na više načina bi želelo $82 \%$ ispitanika. Takođe, čak $84 \%$ korisnika želi aplikaciju koja obezbeđuje pouzdano i tačno informisanje o naplati putarine. Sve veće interesovanje korisnika, kako kod nas tako i u svetu, raste za naplatom putarine bez zaustavljanja i promene brzine. Čak $87 \%$ korisnika su za uvođenje sistema za naplatu putarine bez zaustavljanja i smanjenja brzine vozila. $13 \%$ korisnika nije zainteresovano za ovaj sistem naplate putarine, gde jedan od razloga za to može biti neinformisanost korisnika o prednostima ovog sistema.

Najveći pocenat ispitanika (čak $90 \%$ ) smatra da je nivo usluge viši kod elektronske naplate putarine jer nema vremenskih zadržavanja prilikom naplate kao kod manuelnog sistema za naplatu putarine.
Takođe, $83 \%$ ispitanika smatra da je sa aspekta bezbednosti korisnika na naplatnim stanicama elektronska naplata putarine pogodniji način naplate putarine $u$ odnosu na manuelnu. Sa aspekta vremena putovanja i potrošnje goriva, čak $97 \%$ ispitanika smatra da je elektronska naplata putarine pogodniji način naplate $u$ odnosu na manuelni sistem.

Za 57\% anketiranih korisnika dozvoljena brzina na autoputu, od $120 \mathrm{~km} / \mathrm{h}$, ne predstavlja podobno ograničenje brzine. Korisnici su imali mogućnost da izraze i mišljenje da li je kontrola prosečnih brzina na deonici važna za njihovu bezbednost. 51\% anketiranih se složilo sa navedenom činjenicom, dok $49 \%$ smatra da kontrola brzine smanjuje njihovu koncentraciju i čini ih nervoznim.

Sa Grafikona 2 može se videti da $42 \%$ korisnika smatra da su cene putarine nepristupačne korisnicima, dok $21 \%$ anketiranih smatra suprotno. Neutralan odgovor je dalo $37 \%$ anketiranih korisnika.

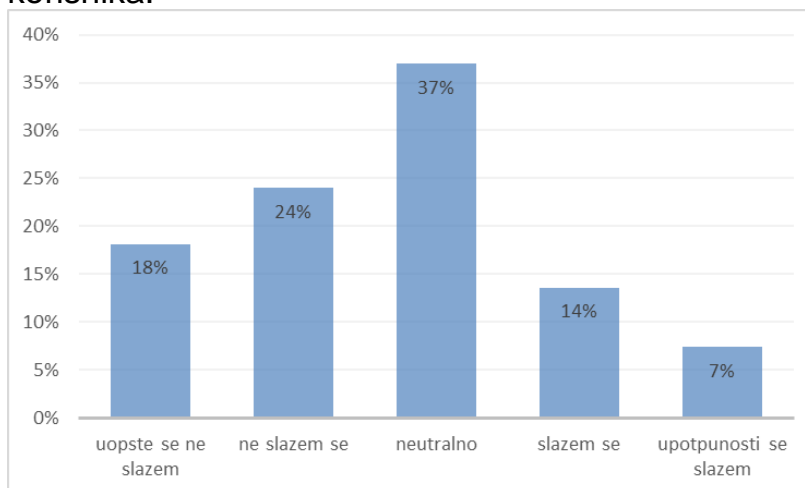

Grafikon 2. Stav korisnika o pristupačnosti cena putarine u Srbiji

Stav korisnika o tome da li su cene putarina veće u Srbiji nego u Evropi nije imalo $36 \%$ ispitanika. Ovakav rezultat se može tumačiti i kao neinformisanost korisnika o cenama naplate putarine na nivou Evrope. 30\% korisnika smatra da su cene putarine veće u odnosu na Evropu, a 35\% korisnika (koji su dali tačan odgovor) se ne slaže sa tom izjavom (Grafikon 3).

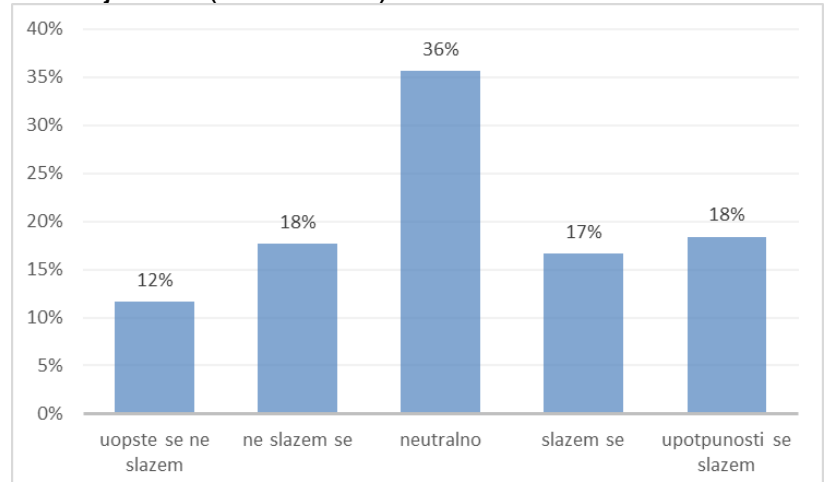

Grafikon 3. Stav korisnika o tome da li su cene putarina veće u Srbiji u odnosu na Evropu 
Najveći procena ispitanika (46\% korisnika) smatra da cene putarine u Srbiji nisu odgovarajuće za bezbednost, brzinu putovanja i udobnost vožnje koju im pruža autoput, $25 \%$ misli da su cene odgovarajuće za uslove autoputeva, dok je 29\% korisnika neutralno po ovom pitanju (Grafikon 4).

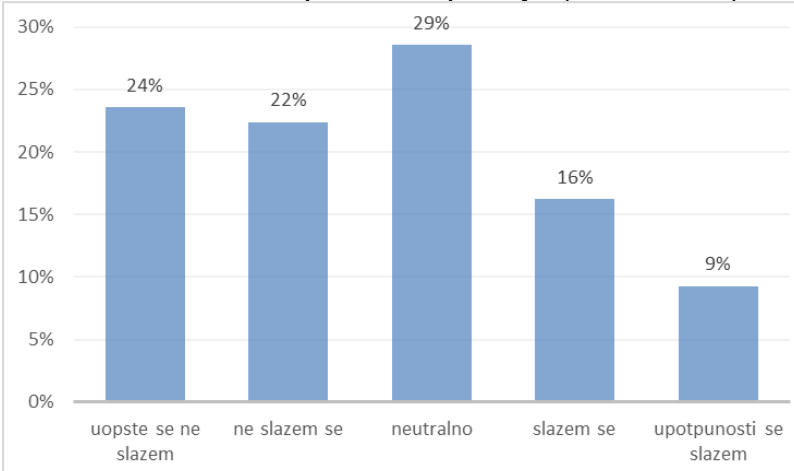

Grafikon 4. Stav korisnika o tome da li su cene naplate putarine ogovarajuće za bezbednost, brzinu putovanja i udobnost vožnje koju pruža autoput

$\mathrm{Na}$ pitanje da li su za uvođenje naplate putarine $u$ vidu vremenske naknade, $45 \%$ anketiranih korisnika se slaže sa uvođenjem ove vrste naknade, dok $22 \%$ korisnika smatra da vremenska naplata nije potrebna (Grafikon 5).

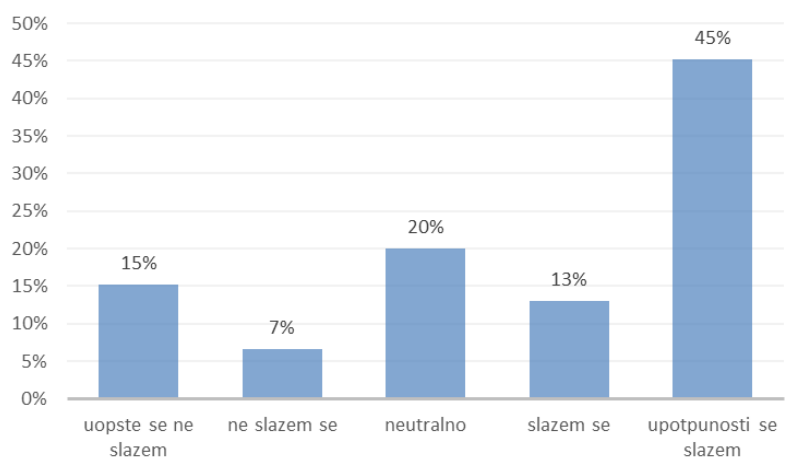

Grafikon 5. Stav korisnika o uvođenju vremenske naknade

$\mathrm{Na}$ pitanje da li bi odustali od vremenske naplate, ako je nepovoljna $u$ odnosu na naknadu po pređenim kilometrima, 51\% anketiranih korisnika se izjasnilo da bi odustali od vremenske naplate, 33\% je neutralno, dok bi samo $16 \%$ korisnika bilo za vremensku naplatu putarine (Grafikon 6).

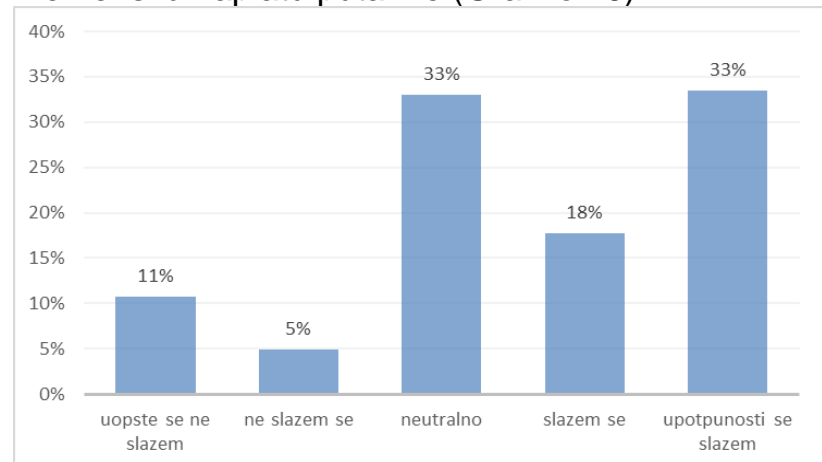

Grafikon 6. Da li bi korisnici odustali od vremenske naplate, ako je nepovoljna u odnosu na naknadu po pređenim kilometrima
Stav većine korisnika (40\%) je da se ne slažu sa povećanjem cene putarine za vozila koja proizvode veću buku na autoputu (Grafikon 7). Ovaj rezultat je očekivan imajući u vidu činjenicu da je vozni park u Srbiji veoma star pa bi povećanje cene obuhvatilo veliki broj korisnika.

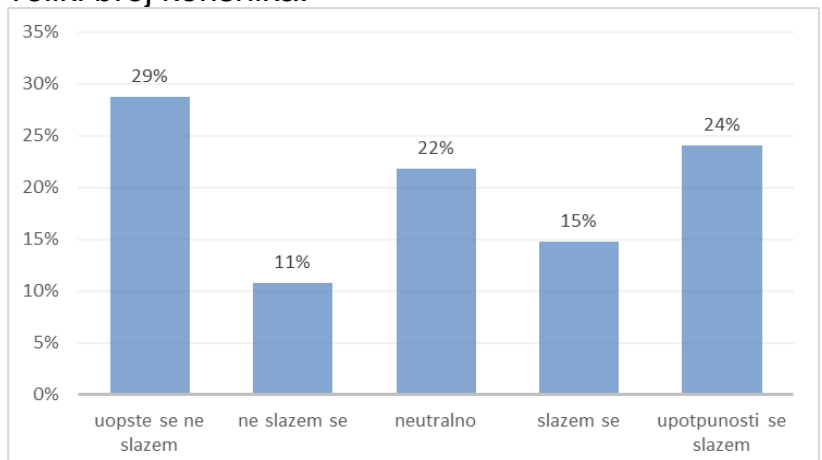

Grafikon 7. Stav korisnika o povećanju cene putarine za vozila koja proizvode veću buku na autoputu

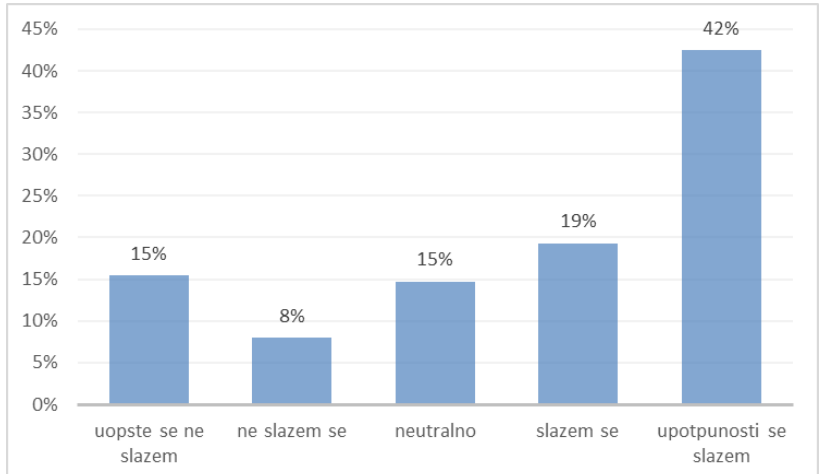

Grafikon 8. Stav korisnika o povećanju cene putarine za vozila koja proizvode veću emisiju polutanata

Zbog povećane svesti korisnika o emisiji zagađenja i šteti po život ljudi, $61 \%$ korisnika je za povećanje cene putarine kako bi se uticalo na promenu voznog parka ili neki drugi alternativni vid prevoza korisnika. $23 \%$ korisnika se ne slaže sa povećanjem cene za vozila koja proizvode veću emisiju zagađenja vazduha (Grafikon 8 ). 39\% anketiranih korisnika je mišljenja da stanje kolovoza u potpunosti nije $u$ skladu sa cenom putarine, a samo $3 \%$ ispitanika se u potpunosti slaže da je cena u skladu sa niovom održavanja kolovoza autoputa (Grafikon 9).

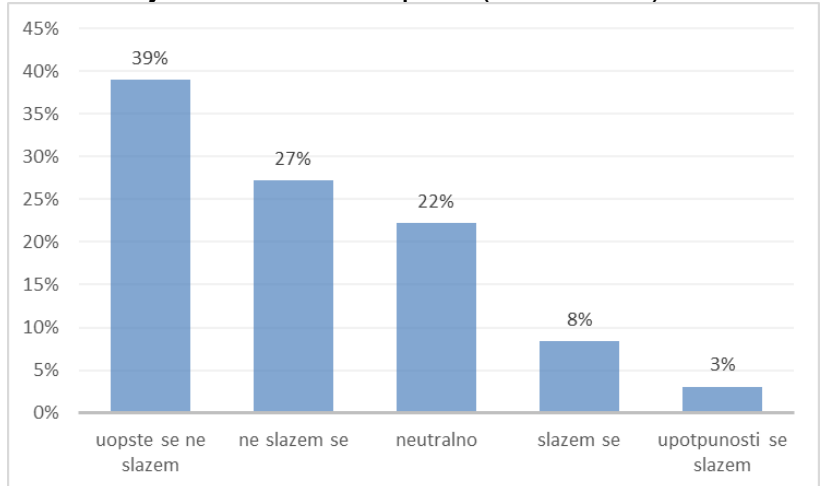

Grafikon 9. Stav korisnika o nivou održavanja kolovoza autoputeva u odnosu na plaćenu cenu 
Stav korisnika po pitanju zimskog održavanja kolovoza je sledeći: $55 \%$ korisnika se ne slaže sa tim da je zimsko održavanje na zadovoljavajućem nivou, u odnosu na plaćenu cenu putarine, dok je $17 \%$ anketiranih korisnika mišljenja da je zimsko održavanje autoputeva na odgovarajućem nivou, u skladu sa plaćenom cenom putarine (Grafikon 10).

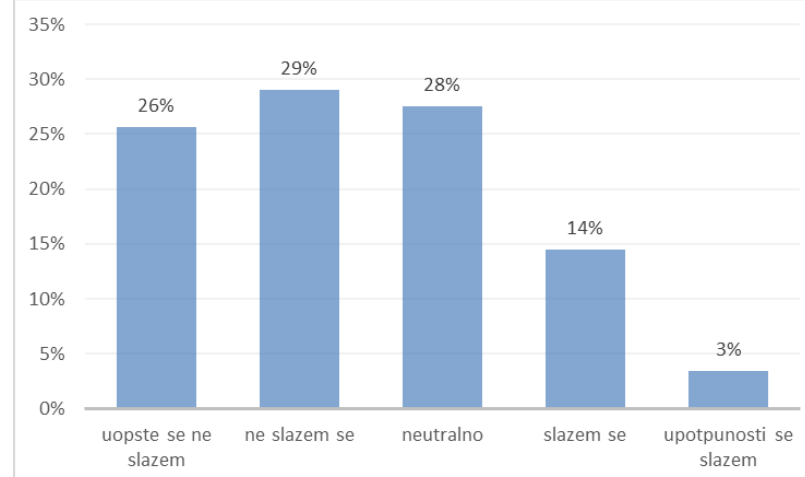

Grafikon 10. Stav korisnika o nivou zimskog održavanja autoputeva u odnosu na cenu putarine

$\mathrm{Na}$ pitanje da li barijere za zaštitu od buke na zadovoljavajućem nivou smanjuju buku koja nastaje kao posledica saobraćaja na autoputevima, 35\% korisnika smatra da barijere značajno smanjuju buku koja nastaje kao posledica saobraćaja, dok $26 \%$ smatra suprotno. Neutralno je bilo $39 \%$ ispitanika (Grafikon 11).

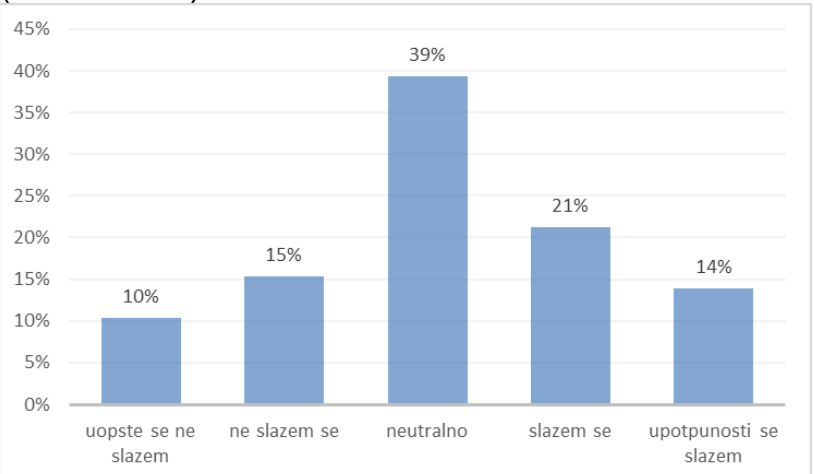

Grafikon 11. Stav korisnika o efektu barijerama za zaštitu od buke

Većina ispitanika (46\%) smatra da zemljišni pojas autoputa nije dovoljno dobro uređen (Grafikon 12).

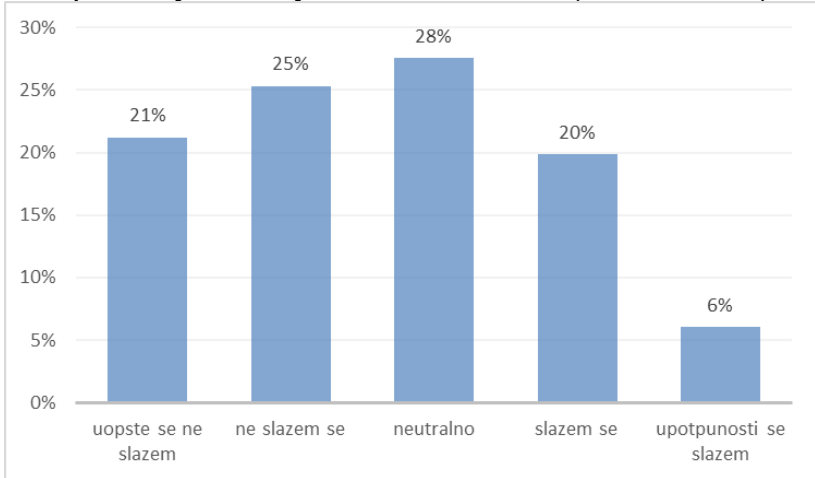

Grafikon 12. Stav korisnika o tome da li je zemljišni pojas autoputa na zadovoljajućem nivou uređen u odnosu na cenu putarine
Među anketiranim korisnicima 30\% njih smatra da prateći sadržaji autoputa nisu adekvatni za korisnike autoputa. 34\% anketiranih se slaže da su prateći sadržaji adekvatni za korisnike, dok je $37 \%$ ispitanika bilo neutralno (Grafikon 13).

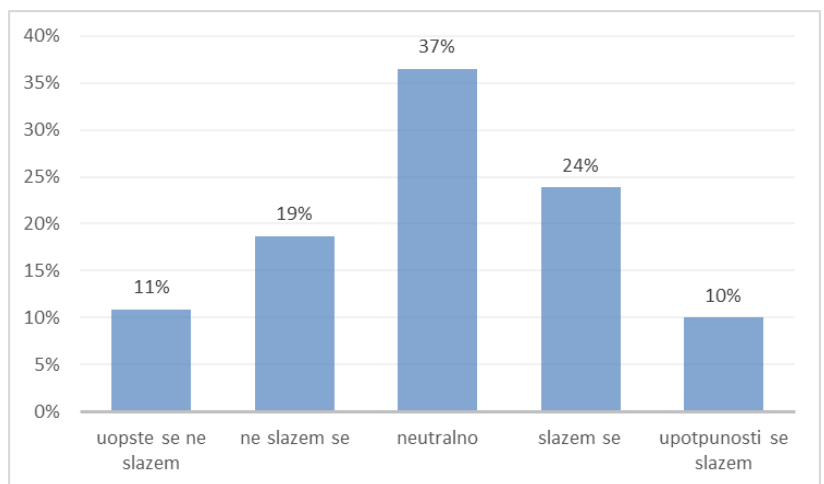

Grafikon 13. Stav korisnika o tome da li su prateći sadržaji autoputa adekvatni za korisnike

Dobijeni rezultati su pokazali da je $87 \%$ anketiranih korisnika mišljenja da loše stanje kolovoza ugrožava bezbednost učesnika u saobraćaju (Grafikon 14).

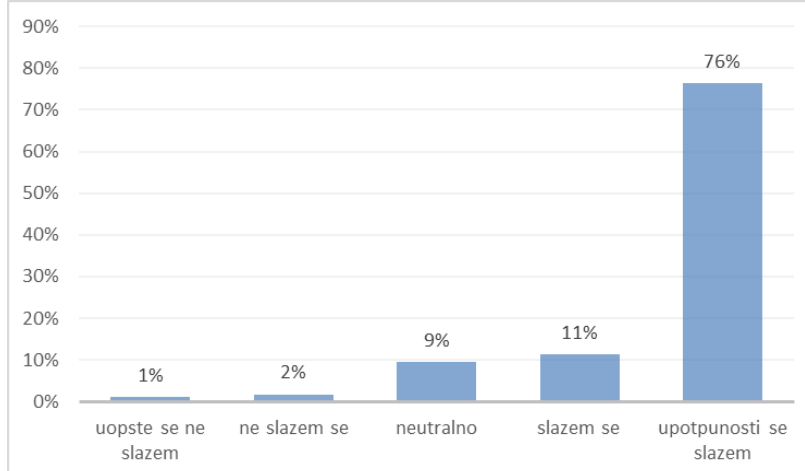

Grafikon 14. Mišljenje korisnika o tome da li stanje kolovoza utiče na bezbednost saobraćaja

Većina ispitanika se slaže sa činjenicom da stanje kolovoza utiče na potrošnju goriva (77\%). Određeni broj ispitanika je neutralan (17\%), dok svega $6 \%$ ispitanika smatra da stanje kolovoza ne utiče na potrošnju goriva.

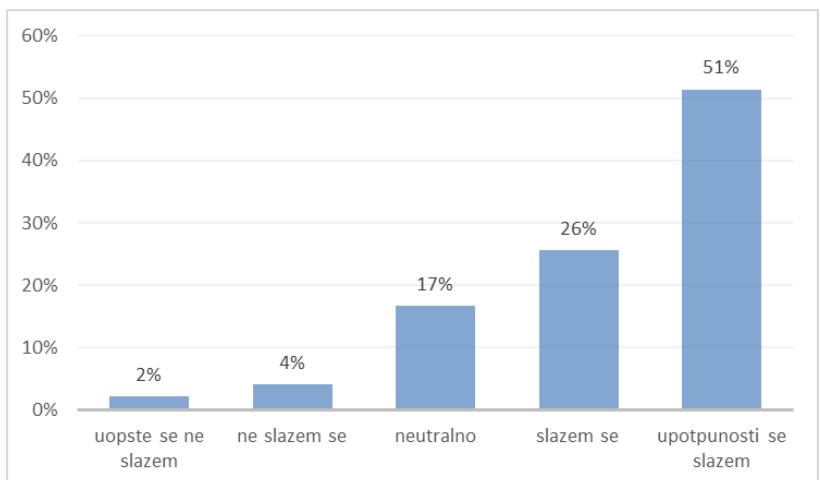

Grafikon 15. Mišljenje korisnika o tome da li stanje kolovoza utiče na potrošnju goriva 
Dobijeni rezultati pokazaju da se većina ispitanika $(75 \%)$ slaže da elektronska naplata putarine doprinosi efikasnosti $i$ tačnosti naplate putarine $u$ odnosu na manuelnu naplatu putarine (Grafikon 16).

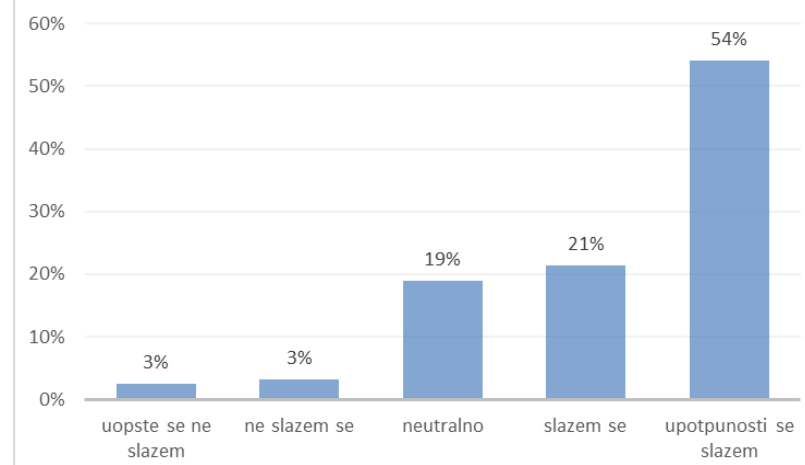

Grafikon 16. Mišljenje korisnika o tome da li elektronska naplata putarine doprinosi efikasnijoj i pouzdanijoj naplati putarine

$86 \%$ korisnika smatra da je prihod od naplate putarine potrebno uložiti u poboljšanje nivoa usluge na autoputu (Grafikon 17).

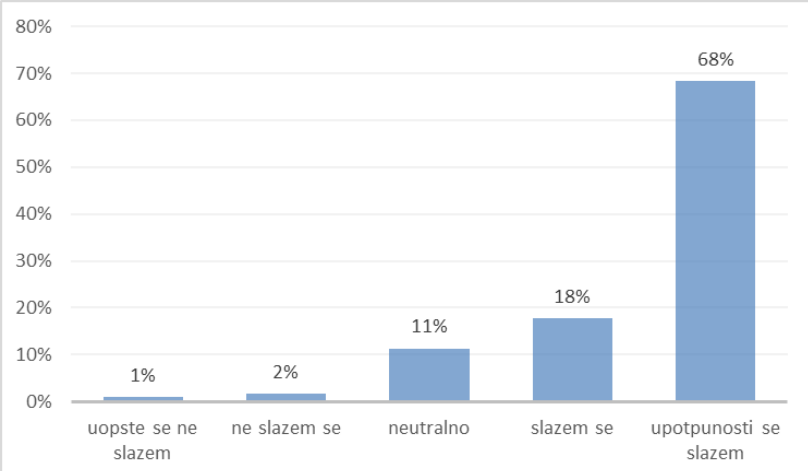

Grafikon 17. Stav korisnika o načinu iskorišćenja prihoda ostvarenog od naplate putarine - ulaganje u nivo usluge na autoputu

Sa stavom da novac od naplate putarine ne treba ulagati u okolne puteve slaže se $55 \%$ anketiranih korisnika. 19\% anketiranih korisnika smatra da novac od naplate putarine treba ulagati i u dvotračne puteve (Grafikon 18).

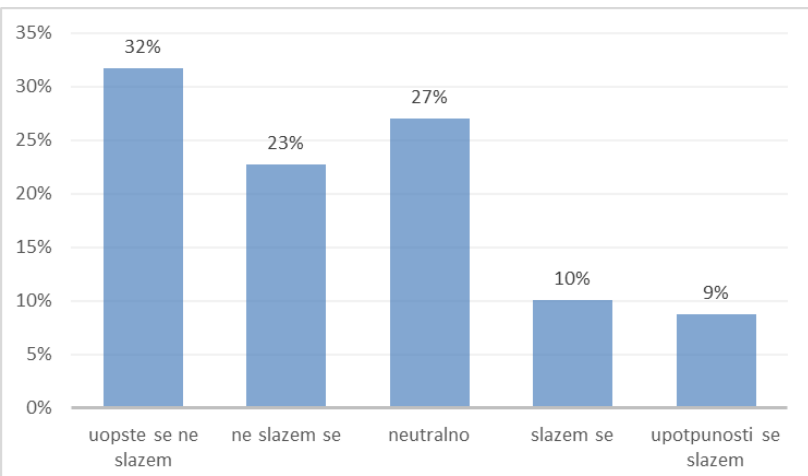

Grafikon 18. Stav korisnika o načinu iskorišćenja prihoda ostvarenog od naplate putarine - ulaganje u ostale kategorije puteva
$\mathrm{Na}$ Grafikonu 19 je prikazan stav korisnika o tome da li bi želeli da imaju mogućnost plaćanja putarine na više načina u zavisnosti od učestalosti korišćenja autoputa.

Sa navedenog grafikona može se videti da je svim grupama korisnika, a posebno ispitanicama koji koriste autoput 1-3 puta mesečno, veoma važna mogućnost plaćanja putarine na više načina.

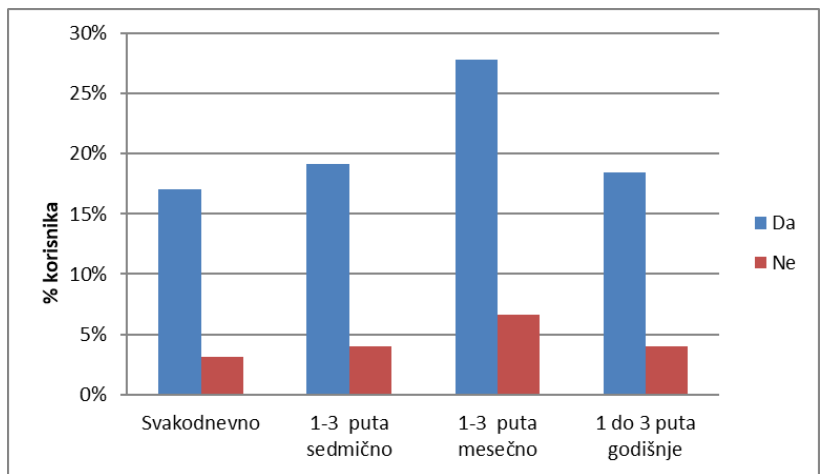

Grafikon 19. Stav korisnika o mogućnostima plaćanja putarine na više načina u zavisnosti od učestalosti korišćenja autoputa

Grafikon 20 prikazuje stav korisnika o uvođenju sistema naplate bez zaustavljanja i/lii smanjenja brzine, u odnosu na učestalost korišćenja autoputa.

Sa grafikona 20 može se videti da je svim grupama korisnika, a posebno onim koji koriste autoput 1-3 puta mesečno veoma važno da imaju sistem naplate putarine bez zaustavljanja i/ili smanjenja brzine.

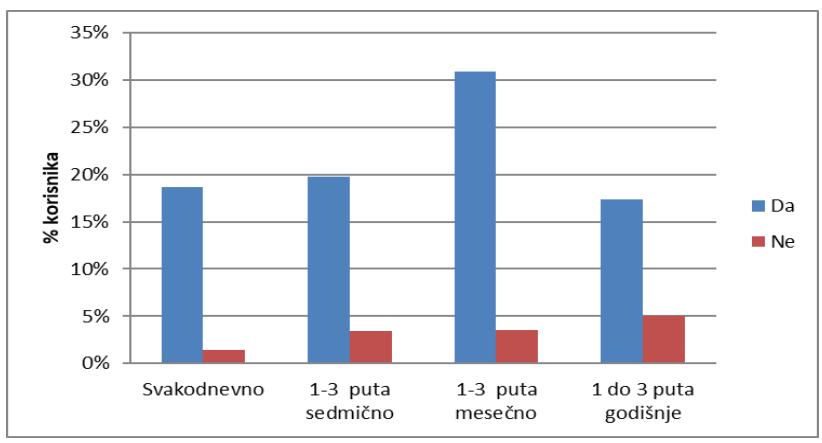

Grafikon 20. Stav korisnika o uvođenju sistema naplate bez zaustavljanja i/ili smanjenja brzine, u odnosu na učestalost korišćenja autoputa

Rezultati ove analize su pokazali da sve grupe korisnika autoputeva poznaju sisteme naplate putarine koji se koriste u Srbiji.

Sa postojećim sistemima za naplatu putarine u Srbiji najmanje su upoznati ispitanici koji koriste autoput 13 puta godišnje (Grafikon 21). 


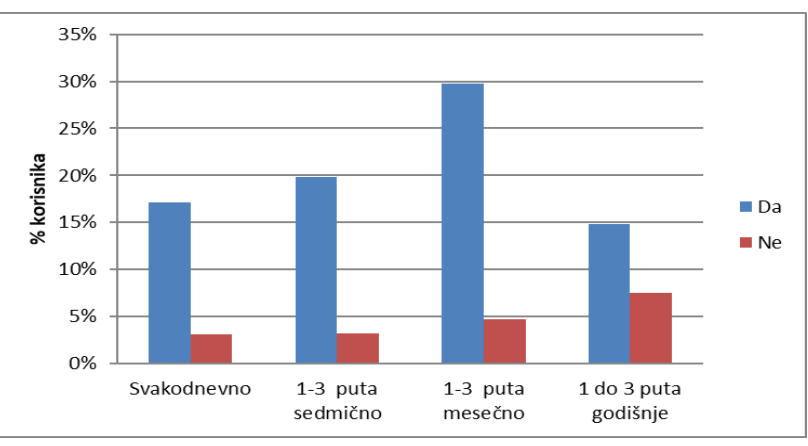

Grafikon 21. Poznavanje sistema za naplatu putarine u Srbiji u zavisnosti od učestalosti korišćenja autoputa

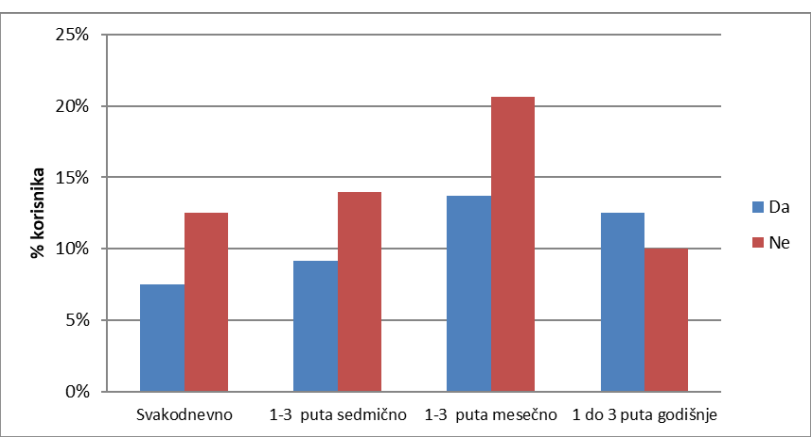

Grafikon 22. Podobnost ograničenja brzine na autoputu od 120 $\mathrm{km} / \mathrm{h}$ sa aspekta korisnika različite učestalosti korišćenja autoputa

Svi korisnici, osim godišnjih, smatraju da ograničenje brzine na autoputu od $120 \mathrm{~km} / \mathrm{h}$ nije podobno za kretanje vozila ovom kategorijom puta (Grafikon 22). Ovaj rezultat ukazuje na jasnu potrebu da se u daljem radu ispita podobnost postojećeg ograničenja brzine na autoputu, kako sa aspekta efikasnosti tako i sa apekta bezbednosti i ekološkog apsekta.

Pored analize podobnosti ograničenja brzine od 120 $\mathrm{km} / \mathrm{h}$ u zavisnosti od učestalosti korišćenja autoputa, sprovedena je i analiza podobnosti navedenog ograničenja $u$ odnosu na pređena rastojanja autoputem od strane korisnika. Da ograničenje od $120 \mathrm{~km} / \mathrm{h}$ nije adekvatno za kretanje vozila autoputem $u$ najvećoj meri smatraju ispitanici koji koriste autoput za rastojanja preko 90 km (Grafikon 23).

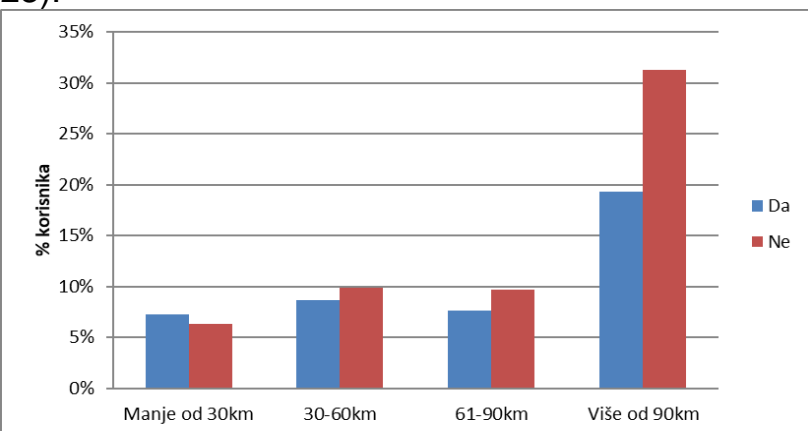

Grafikon 23. Podobnost ograničenja brzine na autoputu od 120 $\mathrm{km} / \mathrm{h}$ sa aspekta korisnika koji na autoputu prelaze različita rastojanja

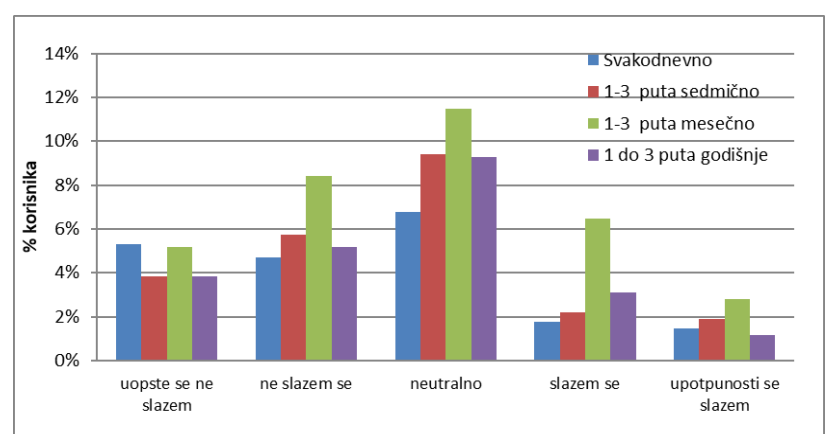

Grafikon 24. Stav korisnika o pristupačnosti cena putarine u Srbiji u zavisnosti od učestalosti korišćenja autoputa

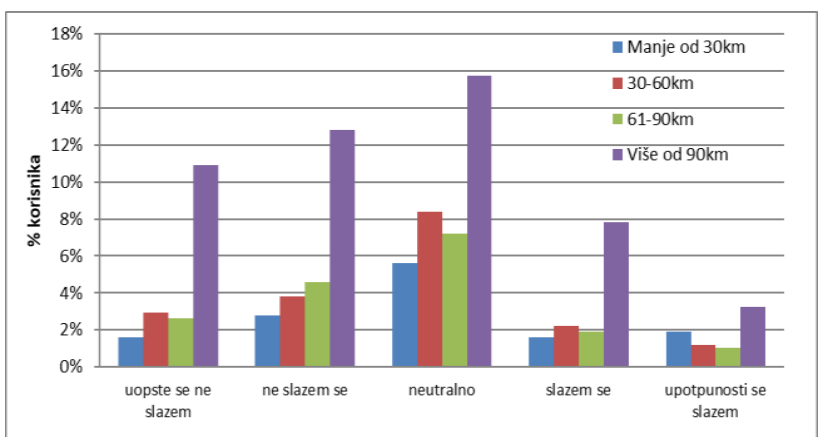

Grafikon 25. Stav korisnika o pristupačnosti cena putarine u Srbiji u zavisnosti od prosečnih pređenih rastojanja na mreži autoputeva

Među korisnicima koji se uopšte ne slažu da su cene putarine pristupačne u Srbiji najviše je svakodnevnih korisnika i onih koji koriste autoput 1-3 puta mesečno (Grafikon 25). Takođe, među korisnicima koji se uopšte ne slažu da su cene putarine pristupačne u Srbiji najviše je onih koji prelaze velika rastojanja veća od $90 \mathrm{~km}$ (Grafikon 26$)$.

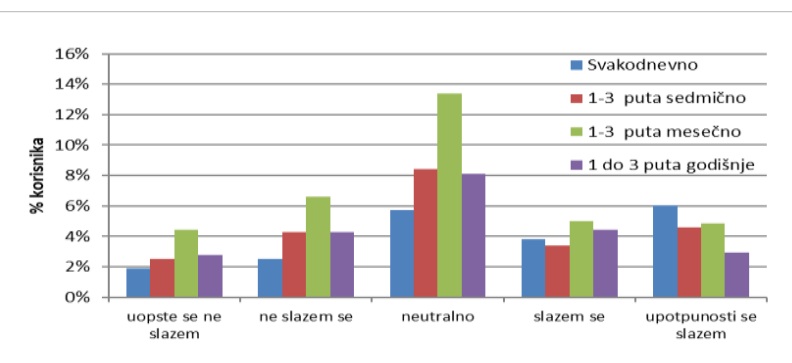

Grafikon 26. Stav korisnika o pristupačnosti cena putarine u Srbiji u odnosu na cene na nivou Evrope u zavisnosti od učestalosti korišćenja autoputa

Među onima koji se uopšte ne slažu da su cena putarine $u$ Srbiji pristupačne, $u$ odnosu na cene putarine na nivou Evrope, najviše je onih koji ređe koriste autoput (1-3 puta mesečno i 1-3 puta godišnje). Nasuprot tome, među ispitanicima koji se u potpunosti slažu sa mišljenjem da su cena putarine u Srbiji pristupačne, u odnosu na cene putarine na nivou Evrope, najviše je onih koji češće korise autoput (Grafikon 26). 


\section{ZAKLJUČAK}

Razumevanje stavova korisnika puteva je preduslov za uspešnu implementaciju i unapređenje sistema za naplatu putarine. Imajući to u vidu, cilj ovog rada je da se utvrde stavovi korisnika autoputeva u Srbiji prema putarinama. Sprovedena anketa je dala odgovore na pitanje da li korisnici puteva razumeju i podržavaju naplatu jer su koristi korišćenja autoputa za vozače višestuko veći od troškova putarine, kao i odgovore na zahteve korisnika po pitanju nivoa usluge na autoputevima.

Dobijeni rezultati su pokazali da trećina ispitanika izbegava korišćenje autoputa i naplatu putarine, odnosno koristi alternativne puteve. Kao glavni razlog za to ispitanici navode cenu putarine (76\%). Među anketiranim korisnicima $88 \%$ je izjavilo da bi se češće kretali autoputem, ako bi tarifiranje putarine bilo povoljnije. $30 \%$ korisnika smatra da su cene putarine veće u Srbiji u odnosu na Evropu, a $35 \%$ korisnika (koji su dali tačan odgovor) se ne slaže sa tom izjavom. Najveći procenat ispitanika (75 \%) smatra da je za svakodnevne korisnike godišnja preplata putarine povoljnija u odnosu na putarinu u skladu sa pređenim kilometrima, dok je za korisnike koji retko koriste autoput (1-3 puta godinje) povoljnija naknada $u$ vidu pređenih kilometara (83\%). Većina ispitanika je za uvođenje vremenske naknade.

Rezultati ankete, koji se odnose na informisanost korisnika, pokazali su da većina ispitanika poseduje određena znanja o sistemima za naplatu putarine i da su za uvođenje naprednih sistema koji ne zahtevaju čekanje u redu niti smanjenje brzine vozila na naplatnim stanicama. Većina ispitanika (preko $80 \%$ ) ima pozitivan stav prema mogućnostima plaćanja putarine na više načina i aplikaciji koja obezbeđuje pouzdano $i$ tačno informisanje o naplati putarine. Takođe, veoma je važno istaći činjenicu da su ispitanici jasno prepoznali prednosti elektronske naplate putarine sa aspekta nivoa usluge, nivoa bezbednosti i troškova eksploatacije vozila. Za $57 \%$ korisnika dozvoljena brzina na autoputu, od $120 \mathrm{~km} / \mathrm{h}$, ne predstavlja podobnu brzinu.

Najveći procenat ispitanika (46\%) smatra da cene putarine u Srbiji nisu odgovarajuće za bezbednost, brzinu putovanja i udobnost vožnje koju im pruža autoput. $39 \%$ ispitanika je mišljenja da stanje kolovoza u potpunosti nije u skladu sa cenom putarine, a samo $3 \%$ ispitanika se u potpunosti slaže da je cena u skladu sa nioom održavanja kolovoza autoputa. Samo $17 \%$ anketiranih korisnika je mišljenja da je zimsko održavanje autoputeva na odgovarajućem nivou, u skladu sa plaćenom cenom putarine. Većina ispitanika $(46 \%)$ smatra da zemljišni pojas autoputa nije dovoljno dobro uređen i $30 \%$ njih smatra da prateći sadržaji autoputa nisu adekvatni za korisnike autoputa. Sa stavom da novac od naplate putarine ne treba ulagati u okolne puteve slaže se $55 \%$ anketiranih korisnika. $19 \%$ anketiranih korisnika smatra da novac od naplate putarine treba ulagati i u dvotračne puteve.

Dobijeni rezultati su ukazali na ključne probleme $u$ postojećem stanju sistema naplate putarine u Srbiji i predstavljaju smernice za unapređenje sistema za naplatu putarine u Srbiji.

\section{LITERATURA}

[1] Odeck, J., \& Bråthen, S. (2002). Toll financing in Norway: The success, the failures and perspectives for the future. Transport Policy, 9(3), 253-260.

[2] Gaunt, M., Rye, T., \& Allen, S. (2007). Public acceptability of road user charging: the case of Edinburgh and the 2005 referendum. Transport Reviews, 27(1), 85-102.

[3] Gomez, J., Papanikolaou, A., \& Vassallo, J. M. (2016). Measuring regional differences in users' perceptions towards interurban toll roads. Journal of Transport Geography, 54, 22-33.

[4] Glavić, D., Milos, M., Luttinen, T., Cicevic, S., \& Trifunovic, A (2017). Road to price: User perspectives on road pricing in transition country. Transportation Research Part A: Policy and Practice, 105, 79-94.

[5] Zmud, J., \& Arce, C. (2008). Compilation of public opinion data on tolls and road pricing (Vol. 377). Transportation Research Board.

[6] Di Ciommo, F., Monzón, A., \& Fernandez-Heredia, A. (2013). Improving the analysis of road pricing acceptability surveys by using hybrid models. Transportation Research Part A: Policy and Practice, 49, 302-316. 